\title{
The Common Roles of Fathers: The Five Ps ${ }^{1}$
}

\section{Garret D. Evans and Kate Fogarty ${ }^{2}$ \\ Overview}

Fathers play many roles in parenting their children. Some are involved in every facet of their child's life while others concentrate on one or two aspects of raising their child. In the United States, the role of the father has changed, with today's fathers taking more responsibility for raising their children.

Have the emotional, personal experiences of fatherhood received greater focus than the traditional role of financial provider? Studies of parenting behaviors suggest that fathers still tend to concentrate their efforts on a handful of basic parenting responsibilities. Today, fathers roles tend to be defined by the "Five Ps":

- participator/problem-solver,

- playmate,

- principled guide,

- provider, and

- preparer.
Before explaining these roles, we need to say that the "Five Ps" are not things a father can do that a mother cannot. Mothers often perform some or all of these roles themselves, quite capably. Rather, they are the roles that fathers define themselves in, because they see them as important activities for raising their child.

\section{Participator / Problem Solver}

Fathers can sometimes overlook the importance of being a regular participator in their child's life. Being there for a child is more than physical presence, but helping to meet children's social, emotional, and psychological needs.

Fathers talk about the importance of helping their child solve many of the critical problems of growing up. These could be the challenges of emerging adulthood such as deciding: what to do for a living, whether to go to college, whether to buy a car; or, they could be everyday tasks such as homework, fixing a bike, or hanging a swing from a tree.

In the problem-solver role, dads are modeling effective problem-solving skills for their child. They have an opportunity to show their child how to make

1. This document is FCS2140, one of a series of the Family, Youth, and Community Sciences Department, Florida Cooperative Extension Service, Institute of Food and Agricultural Sciences, University of Florida. Publication: December 1999. Revised: August 2005. Please visit the EDIS Web site at http://edis.ifas.ufl.edu.

2. Garret D. Evans, Psy.D., former assistant professor in Clinical Psychology, and Kate Fogarty, Ph.D., assistant professor, Youth Development, both of the Department of Family, Youth and Community Sciences, Florida Cooperative Extension Service, Institute of Food and Agricultural Sciences, University of Florida, Gainesville FL 32611.

The Institute of Food and Agricultural Sciences (IFAS) is an Equal Opportunity Institution authorized to provide research, educational information and other services only to individuals and institutions that function with non-discrimination with respect to race, creed, color, religion, age, disability, sex, sexual orientation, marital status, national origin, political opinions or affiliations. U.S. Department of Agriculture, Cooperative Extension Service, University of Florida, IFAS, Florida A. \& M. University Cooperative Extension Program, and Boards of County Commissioners Cooperating. Larry Arrington, Dean 
and act on decisions, as well as experience the consequences of their actions and decisions. This process fosters a child's responsibility, independence, and self-reliance. If children are raised without a role model for effective problem-solving, they often adopt poor strategies that lead them to become ineffectual and helpless in problematic situations. Children and adults with deficient problem-solving skills often become needy and dependent on others to "make things right" in their life. On the positive side, fathers who model healthy problem-solving in relationships have children who are less aggressive and who are more popular with their peers and teachers.

While fathers often play a critical role in their child's life by setting an example of problem-solving, fathers sometimes get involved in solving problems when it's nearly too late. In some family situations, a father only gets involved when a child's emotional and behavioral problems have become so serious that they are less responsive to treatment. Reserving dad's help for only the "big" problems is a big mistake. Fathers need to be involved in all phases of their child's problem-solving strategies from serving as an example to serving as a guide who offers possible solutions to their child(ren).

\section{Playmate}

Fathers can be great jungle gyms. Research shows that fathers spend more time, proportionally, with their children in high-energy, physical play than do mothers. In addition, fathers tend to engage in more roughhousing and stimulating play than mothers, for example, using the elements of surprise and excitement. This sets up expectations in children for the majority of their interactions with fathers involving physical play. For example, a daughter hangs on her father's arm and wants to swing as soon as he comes through the front door on his way home from work. Still, this type of play can be very important in a child's life. Physical play not only builds muscles and coordination, but can often be used to teach rules that govern behavior (e.g., taking turns, standing in line, playing physically without injuring someone, etc.). Through the role of playmate, a father can encourage his child's sense of autonomy and independence, which is a major milestone of social and emotional growth.
In addition, play is often termed a "window to the child's world." This means that play can often be used to find out about a child's thoughts, feelings, hopes, and dreams. Fathers can also use play to informally start a serious conversation with their child. In fact, it's important that fathers use this time to talk with their child and to build their emotional bond with them. Too often, fathers miss this opportunity by simply playing and substituting physical contact for verbal interaction.

\section{Principled Guide}

The cliché, "Wait til your father gets home!" no longer applies due to the diversity of family types as well as a new understanding of child discipline as guidance, not punishment. Neither should "punisher" be used to describe a father's role, especially because punishment tends to be a negative assertion of adult power. Punishment emphasizes to children what they should not do, rather than how parents would like them to act. Also, punishment may be the result of a parent's emotional reaction to a childs behavior. As a result, a child may feel shamed and humiliated which undermines trust in the parent-child relationship. Also, the child's sense of autonomy and initiative may be undermined, especially when a child's unacceptable behavior is well-meaning. Guidance, on the other hand teaches socially desirable behavior, helps children to learn the difference between right and wrong, and enables children to experience and understand the consequences of their own behavior.

Fathers who serve as guides for their children maintain their authority, but use it effectively. Guidance is a collaborative effort between parent and child that involves an ongoing process of father-child interaction. Agreement between fathers and mothers on guidance strategies is important, particularly when it comes to learning consequences of unacceptable behavior. If one parent allows the child to experience the consequences of his/her poor decision and the other rescues the child from that experience, there will be harmful effects to both the parental relationship and the child's development.

Just as important, when fathers become over-involved in punishing, they often have far too little involvement in rewarding good behaviors. 
Fathers who want to build a healthy bond with their child need to use appropriate guidance. This guidance must be a balance between correcting unacceptable behavior and encouraging with praise and other rewards for successful behavior.

\section{Provider}

While, in the last few decades, mothers of dependent children have entered the work force in unprecedented numbers, men continue to be identified as the primary "breadwinner" for the family. This is not always the case, as some fathers choose to be the primary providers of childcare, for example, while working out of the home or continuing their education. Also, with the increase in divorce and parenting outside of marriage, many mothers have become the main providers for their families.

American society still values the ability of the father to provide tangible resources (i.e., food, money, shelter, material possessions) for their children. For example, policies enforcing a non-resident father's payment of child support reflect such values. Also, an emphasis on responsible fatherhood has influenced social policy and social movements (e.g., the Promise Keepers) in the 1990s through the new millennium.

More than the provision of material things (e.g., income and resources) for children and families, a fathers provider role can be defined in terms of responsibility for care of the child. For example, fathers may help to make plans and arrangements for child care, even if they are not directly providing care. All too often, fathers have been led to believe that providing income and material support is all there is, their only way for caring for their family. That's unfortunate, because it discourages fathers from participating in all of the other parenting activities that many find so fulfilling, such as guidance, play, and school activities. Further, if a father values his role as a parent solely only in terms of providing material resources for the family, he may begin to feel trapped by his employment. Placing a bulk of the emphasis on a fathers being the provider can prevent his leaving unsatisfying, well-paying employment. He may not feel able to risk (even a temporary) decrease in family income while he looks for other employment opportunities.

\section{Preparer}

Fathers often see themselves as someone involved in preparing their children for life's challenges, as well as protecting them when necessary. They may talk with their child about family values and morals. Or, fathers may advise their teenagers about educational and employment goals as well as give advice (when asked for) about peer and romantic relationships. They may guide their child about how to behave in school and work to ensure their child's success in those areas. They may discuss the importance of being truthful, of giving an "honest day's work for an honest day's pay", or showing their affection to a spouse or partner.

Often, fathers see their relationship with their child blossom as the child grows into adolescence and adulthood. Some fathers even see this as the time to get involved in preparing their children for the "real world." In truth, fathers don't need to wait until their children are becoming adults in order to teach them important life lessons. Fathers can provide moral guidance and practical lessons all the way through their child's life. This kind of involvement strengthens the father-child relationship. Involvement helps build an ongoing partnership between father and child. Most important, through his influence on many areas of his child's life, a father teaches his child how to be a parent.

\section{The Five Ps: Is That All There Is?}

While the "The Five Ps" can be a simple guide for categorizing ways that fathers are commonly involved in their child's life, there's no need to restrict your role as a father to these 5 categories. However, the diverse nature of activities fathers are involved in today tend to fit, more or less, into one of the five Ps. For example, if a father acts as a primary caretaker for his children, the activities he engages in will fit into all 5 categories. Activities such as feeding, bathing, and transporting all fit into the expanding definition of a father's provider role. The benefits of this expanded involvement are clear for both the child and the father (see: "The Hidden Benefits of Being an Involved Father" Florida 
Cooperative Extension Service, IFAS, Univ. Fla., Gainesville FCS2137

http://www.edis.ifas.ufl.edu/HE137). Fathers who look for a variety of ways to be involved in their child's life contribute to a healthier family and a healthier future for their child.

\section{References}

Gordon, A., \& Browne, K.W. (1996). Guiding young children in a diverse society. Boston, MA: Allyn \& Bacon.

Jain, A., Belsky, J. \& Crnic. K. (1996). Beyond fathering behaviors: Types of dads. Journal of Family Psychology, 10, 431-442.

Kazura, K. (2000). Fathers qualitative and quantitative involvement: An investigation of attachment, play, and social interactions. The Journal of Mens Studies, 91, 41-57.

Marsiglio, W., Amato, P., Day, R.D., \& Lamb, M.E. (2000). Scholarship on fatherhood in the 1990s and beyond. Journal of Marriage \& the Family, 62, 1173-1191.

Marsiglio, W. (1995). Fatherhood:

Contemporary theory, research, and social policy. Thousand Oaks, CA: Sage.

Palkovitz, R. (2002). Involved fathering and child development: Advancing our understanding of good fathering. In C.S. Tamis-LeMonda \& N.

Cabrera (Eds.), Handbook of father involvement: Multidisciplinary perspectives. Mahwah, NJ: Lawrence Erlbaum (pp. 119-140).

Parke, R.D., McDowell, D.J., Kim, M., Killian, C., Dennis, J., Flyr, M.L., \& Wild, M.N. (2002).

Fathers contributions to childrens peer relationships. In C.S. Tamis-LeMonda \& N. Cabrera (Eds.), Handbook of father involvement: Multidisciplinary perspectives. Mahwah, NJ: Lawrence Erlbaum (pp. 141-167). 